STUDIA PRAWNO-EKONOMICZNE, T. CXI, 2019

PL ISSN 0081-6841; e-ISSN 2450-8179 $\quad$ s. 97-116

https://doi.org/10.26485/SPE/2019/111/6

\title{
Adam ŚWIĘTOŃ*
}

(iD) https://orcid.org/0000-0001-5292-2849

Konrad TADAJCZYK**

iD https://orcid.org/0000-0002-2487-8163

\section{HADRIAN WOBEC DZIECI ŻOLNIERZY - UWAGI NA TLE EPISTULA HADRIANI DE BONORUM POSSESIONE LIBERIS MILITIUM DANDA}

\begin{abstract}
(Streszczenie)
Opracowanie poświęcone jest analizie przywileju nadanego żołnierzom armii rzymskiej przez cesarza Hadriana w odniesieniu do prawa dziedziczenia przez ich dzieci pochodzące ze związków pozamałżeńskich. Począwszy od I w. n.e., żołnierze służący w legionach nie mogli zawrzeć ważnego małżeństwa. Wprowadzenie takiego uregulowania tłumaczy się najczęściej troską o utrzymanie disciplina militaris. W konsekwencji związki żołnierzy posiadających obywatelstwo rzymskie z obywatelkami rzymskimi lub peregrynkami nie rodziły żadnych skutków prawnych, nawet mimo potencjalnego istnienia conubium pomiędzy partnerami. Dzieci pochodzące z takich związków (liberi illegitimi) nie wchodziły pod władzę swoich ojców ani nie nabywały praw spadkowych w jego rodzinie. Żołnierz mógł jedynie powołać do dziedziczenia pozamałżeńskie dziecko, mające status prawny Latyna lub peregryna, sporządzając testament żołnierski (testamentum militis). W liście wydanym w 119 r. n.e. cesarz Hadrian usunął tę niedogodność, pozwalając dziedziczyć żołnierskim liberi illegitimi także wówczas, gdy żołnierz nie pozostawił testamentu. Byli oni powoływani do spadkobrania w klasie unde cognati. Autorzy przybliżają okoliczności ogłoszenia przywileju i omawiają skutki, jakie wywołał on na gruncie rzymskiego prawa spadkowego.
\end{abstract}

Słowa kluczowe: prawo rzymskie; prawo spadkowe; armia rzymska

* Dr, Uniwersytet Warmińsko-Mazurski w Olsztynie, Wydział Prawa i Administracji, Katedra Prawa Rzymskiego, Teorii i Filozofii Prawa oraz Komparatystyki Prawniczej; e-mail: adamswieton75@gmail.pl

** Dr, Uniwersytet Łódzki, Wydział Prawa i Administracji, Katedra Prawa Rzymskiego, e-mail: tktadajczyk@wpia.uni.lodz.pl 
Cesarz Hadrian, sprawny administrator i reformator cesarstwa rzymskiego, poświęcał wiele uwagi kwestiom bezpieczeństwa państwa. Wprowadził dużo istotnych zmian w funkcjonowaniu armii - usprawnił politykę rekrutacji, zwiększając dostęp do legionów dla mieszkańców prowincji, troszczył się o utrzymanie dyscypliny wojskowej i o dobre relacje cesarza z żołnierzami. Jednym z przykładów takiej polityki jest uregulowanie dotyczące dziedziczenia przez żołnierskie dzieci, ogłoszone na początku panowania w 119 r. Dokument zawierający treść beneficium nie zachował się w języku łacińskim, a jedynie jako odpis na papirusie w języku greckim. Odnaleziony w Fayum, znajduje się on obecnie w Ägyptisches Museum und Papyrussammlung w Berlinie'. Papirus w kształcie prostokąta o wymiarach $10 \mathrm{~cm}$ na $22 \mathrm{~cm}$ został opublikowany po raz pierwszy przez Urlicha Wilckena, który początkowo przypisał autorstwo tekstu Trajanowi². Później zrewidował pogląd, uznając autorstwo Hadriana ${ }^{3}$. Kolejne objaśnienia zostały dodane przez P. Meyera ${ }^{4}$, a następnie liczne grono historyków i badaczy praw antycznych ${ }^{5}$.

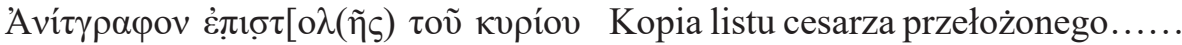
$[-\mu \varepsilon] \theta \eta \rho \mu[\eta v] \varepsilon v-\mid \mu \varepsilon ́ v \eta \varsigma \ldots(\omega) \quad[\hat{\eta}(?) \mid$ który w trzecim roku...... za konsula-

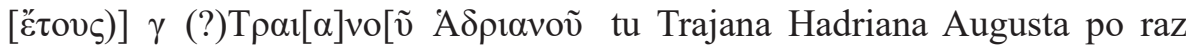
$\Sigma \varepsilon \beta \alpha \sigma \tau \mathrm{o}] \tilde{v}<\tau$ ò $\quad \gamma>\quad \mid \quad[$ Пov $] \pi \lambda i$ íov

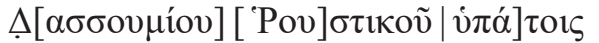
$\pi \rho \circ \varepsilon[\tau \dot{\varepsilon} \theta \eta \dot{\varepsilon} v \quad . . . . . . \tau \tau \tilde{\eta} \pi \alpha \rho \varepsilon \mu \beta \mathrm{o} \lambda(\tilde{\eta})]$

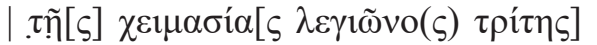

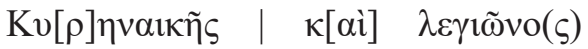

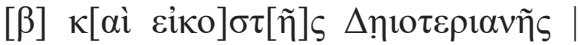

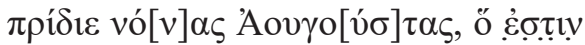

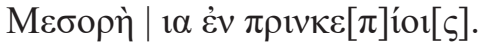
trzeci i Publiusza Dasomiusza Rustyka została zawieszona przy głównej drodze w obozie zimowym trzeciego legionu Cyrenajskiego i dwudziestego drugiego legionu Dejotariańskiego dzień przed nonami sierpnia, które wypadają jedenastego dnia miesiąca Mesore.

1 S. Riccobono, FIRA, vol. I, Firenze 1941, nr 78, s. 428-430.

2 U. Wilcken, Aegyptische Urkunden aus den Königlichen Museen zu Berlin, Griechische Urkunden I, Berlin 1901, n. 140.

3 U. Wilcken, Ein Neuer Brief Hadrians, Hermes 1902/37, s. 84-90.

4 P. Meyer, Die ägyptischen Urkunden und das Eherecht der römischen Soldaten, ZSS 1898/18, s. $44-74$.

5 Zob. E.M. Smallwood, Documents Illustrating the Principates of Nerva Trajan and Hadrian, Cambridge 1966, s. 114 i n., nr 333, a także J.H. Oliver, Greek constitutions of Early Roman Emperors from Inscriptions and Papyri, Philadelphia 1989/70, s. 167-170. 


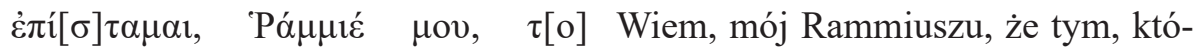

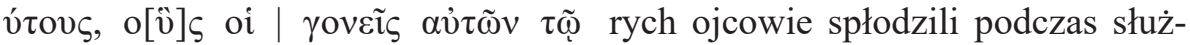

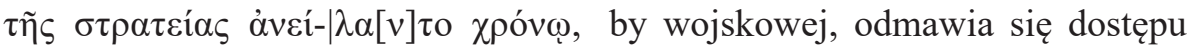

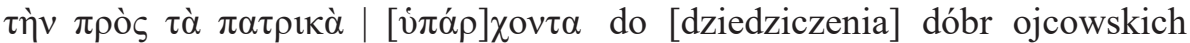

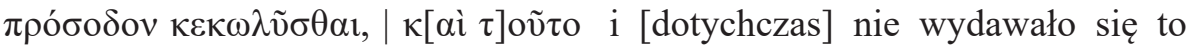

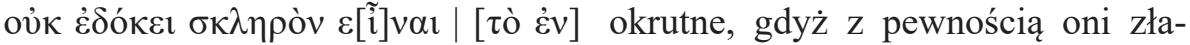
$\alpha v \tau i ́ o v \alpha \hat{\tau} \tilde{\omega} v \tau \tilde{\eta} \varsigma \sigma \tau \rho \alpha \tau \imath \omega[\tau \imath] \kappa \tilde{n}[\varsigma] \mid$ mali dyscyplinę wojskową. Jednakże $[\delta 1 \delta \alpha] \chi \tilde{\eta} \varsigma \pi \varepsilon \pi \circ \eta \eta \kappa o ́ \tau \omega v . \eta \eta \eta \delta เ \sigma \tau \alpha \delta \dot{\varepsilon} \mid$ ja bardzo chętnie korzystam z okazji,

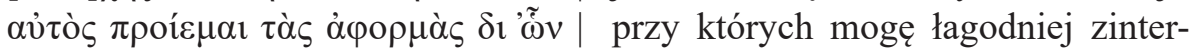

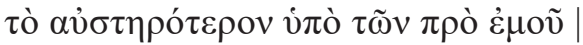

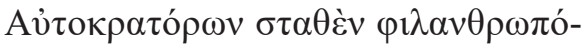

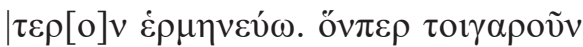

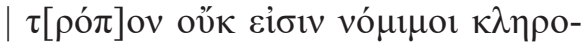
|[vó $\mu]$ or $\tau \tilde{\omega} v \dot{\varepsilon} \alpha v \tau \tilde{\omega} v \pi \alpha \tau \dot{\varepsilon} \rho \omega v$ oi $\tau \tilde{\omega}$

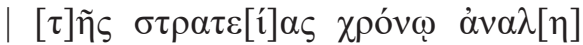
$\mu \varphi \theta \dot{\varepsilon} v-\mid \tau \varepsilon \varsigma, \quad$ ő $\mu \omega \varsigma \kappa \alpha \tau[\mathrm{o}] \chi \grave{\eta}[v] \dot{v}[\pi \alpha]$

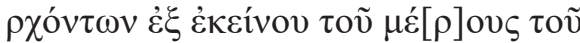

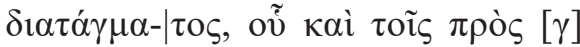

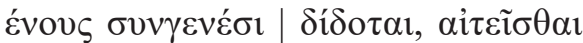

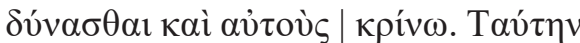

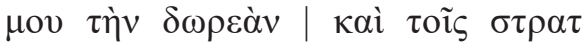

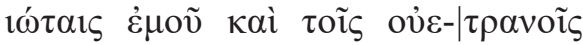

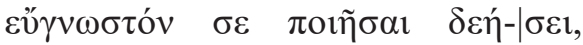

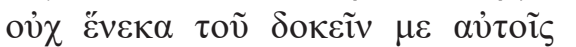

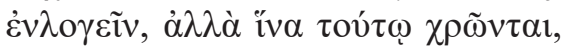
$\dot{\varepsilon} \alpha \grave{\alpha} v \dot{\alpha} \gamma v o \tilde{\omega} \sigma \mathrm{l}$

pretować to, co poprzedni cesarze postanowili z większą surowością. Chociaż zatem nie są prawnymi spadkobiercami swoich ojców ci, których spłodzono podczas służby wojskowej, postanawiam jednak, że oni również mogą ubiegać się o objęcie w posiadanie dóbr na podstawie tej części edyktu, na podstawie której przyznano [tę możliwość] również krewnym kognacyjnym. Tę moją laskawość [przywilej] powinieneś ogłosić publicznie moim żołnierzom i weteranom nie po to, aby się wydawało, że ja domagam się od nich wdzięczności za to, ale po to, by z niej korzystali, jeśli dotychczas o niej nie wiedzieli.

Epistula $^{6}$ została wydana, jak informuje nas tekst w nagłówku, w roku, w którym cesarz Hadrian sprawował swój trzeci konsulat wraz z Publiuszem Dasumiuszem Rustykiem, a więc w roku $119^{7}$. Z uwagi na fakt, iż Hadrian pia-

6 O epistula jako dokumencie urzędowym w okresie panowania Hadriana zob. F. Martin, La documentacion gregia de la cancilleria del emperador Adriano, Pamplona 1982, s. 287 i n. Zob. także K. Kłodziński, Sekretarze ab epistulis $i$ a libellis $w$ kancelarii cesarzy od Augusta do Hadriana, Toruń 2011, s. 84. Autorzy będą posługiwać się w dalszej części tekstu zamiennie określeniem „list”.

7 A. Degrassi, I Fasti Consolari dell'Impero Romano: dal 30 avanti Cristo al 613 dopo Cristo, Roma 1952, s. 35. 
stował w tym roku godność konsula tylko 4 pierwsze miesiące ${ }^{8}$, wydanie listu musiało nastąpić w tym czasie.

Dokument został skierowany do rąk prefekta Egiptu Kwintusa Rammiusza Marcjalisa ${ }^{9}$ i trafił do adresata najpóźniej w początkach sierpnia, gdyż czwartego dnia tego miesiąca jego treść została upubliczniona w zimowym obozie wojskowym (hibernia) legionów III Cyrenajskiego (Cyrenaica) i XXII Dejotariańskiego (Deiotariana $)^{10}$. Obóz ten znajdował się w Nikopolis, ok. $5 \mathrm{~km}$ na wschód od Aleksandrii ${ }^{11}$. Legiony odpoczywały w nim po udziale w podjętej jeszcze przez Trajana wyprawie partyjskiej, $\mathrm{z}$ której powróciły $\mathrm{w}$ tym roku ${ }^{12}$.

Prezentowana powyżej wersja sporządzona została w języku greckim, jednakże, zdaniem S. Phang, list dotarł do rąk Rammiusza w wersji łacińskiej i dopiero na miejscu dokonano przekładu ${ }^{13}$. Jest to najbardziej prawdopodobna wersja wydarzeń, zważywszy na fakt, że jego odbiorcą był rzymski urzędnik, który zarządził upublicznienie tekstu. Decyzja o dokonaniu przekładu wynikała ze składu osobowego legionów III i XXII, który stanowili także żołnierze posługujący się językiem greckim jako powszechnym dla wschodniej części imperium.

Obecność w legionach stacjonujących w prowincjach rzymskiego wschodu dużej liczby żołnierzy posługujących się greką była rezultatem zmiany w polityce rekrutacyjnej - w okresie pryncypatu stopniowo odchodzono od praktyki

De vita Hadriani, 8.5.

9 Na temat Rammiusza Marcjalisa zob. A. Stein, Rammius 2, w: W. Kroll, K. Witte (Red.), Paulys Real-Encyclopädie der Classischen Altertumswissenschaft. Zweite Reihe [R-Z] Erster Halbband, Stuttgart, kol. 135-136.

10 Zanim dokonano publikacji tekstu przez zawieszenie go na murach obozu, jego treść prawdopodobnie została odczytana na codziennym porannym apelu, który był rutynowym wydarzeniem w obozie, i podczas którego zbierano raporty, odczytywano dzienne rozkazy, oficjalne pisma i przekazywano ważne informacje. Zob. R.W. Davies, The Daily Life of Roman Soldier under the Principate, ANRW 2.1, Berlin-New York 1974, s. 314.

11 J.F. Gilliam, The veterans and praefectus castrorum of the II Traiana A.D. 157, w: J.F. Gilliam, Roman Army Papers, Amsterdam 1986, s. 152, przyp. 28, a także P.-L. Gatier, La Legio III Cyrenaica et l'Arabie, w: Y. Le Bohec (réd.), Les legions de Rome sous le Haut-Empire. Actes du Congrès de Lyon (17-19 septembre 1998), Lyon 2000, s. 343. Na temat lokalizacji obozu zob. R. Alston, Soldiers and society in Roman Egypt. A social history, London-New York 1995, s. 192 i n.; M.C. Bishop, Handbook to Roman Legionary Fortresses, Barnsley 2012, s. 48.

12 Z całą pewnością zaangażowano legion III, nie ma pewności, czy w wyprawie wziął udział także legion XXII, czy tylko oddziały z niego wydzielone, zob. J.F. Gilliam, An Egyptian cohort in A.D.117, Bonner Historia-Augusta-Colloquium 1964/1965, pod red. A. Alföldi, Bonn 1966, s. 95

13 S.E. Phang, The Marriage of Roman Soldiers (13 B.C.-A.D. 235): Law and Family in the Imperial Army, Leiden-Boston-Köln 2001, s. 39. 
polegającej na przyjmowaniu do legionów jedynie posiadających obywatelstwo rzymskie mieszkańców Italii. Początkowo czyniono to sporadycznie i w sytuacjach wyjątkowych. Jeszcze u schyłku republiki Cezar stworzył legion z galijskich ochotników ${ }^{14}$. W I w. zezwalano na zaciąg obcokrajowców ${ }^{15}$, tworząc legiony składające się nawet $\mathrm{w}$ całości z peregrynów ${ }^{16}$. Już w II w. n.e. relatywnie często dokonywano zaciągu rekruta w prowincji, w której stacjonował legion - w przypadku Hadriana takie postępowanie było wynikiem przyjętej przez niego polityki defensywnej, polegającej na obronie granic Cesarstwa i ściślejszym związaniu legionu z prowincją, której bronił; bez wątpienia za przyjęciem takiej polityki rekrutacyjnej przemawiały także względy ekonomiczne ${ }^{17}$. Problem braku civitas Romana omijano poprzez nadanie obywatelstwa żołnierzom na początku służby ${ }^{18}$. W drugiej połowie II w. zdecydowano się na kolejne odstępstwa od wymagań formalnych: do służby zaczęto powszechnie dopuszczać urodzone w obozie (in castra nati) dzieci żołnierzy, mimo iż ta kategoria rekrutów również nie miała obywatelstwa Rzymu ${ }^{19}$.

Powstaje pytanie, jak duża część żołnierzy legionów III i XXII pochodziła ze wschodnich obszarów Cesarstwa. Względy praktyczne podyktowane m.in. miejscem operowania tych legionów, wskazywałyby na lokalne społeczności jako główne źródło zaciągu ${ }^{20}$. Z pewnością już w I w. znacząca liczba służących w nich żołnierzy rekrutowała się z obszarów greckojęzycznych. Na podstawie zachowanych z tego okresu inskrypcji powiązanych ze wspomnianymi legionami można wnioskować o miejscu pochodzenia żołnierzy: na 61 jedynie 8 po-

14 Sformowany w 51 r. p.n.e. z mieszkańców Galii Zaalpejskiej legion określany przydomkiem Alauda stał się pełnoprawnym legionem (legio iusta) po nadaniu jego żołnierzom civitas Romana w 47 r. p.n.e. Zob. A. Krawczuk, Virtutis ergo. Nadania obywatelstwa rzymskiego przez wodzów republiki, Kraków 1963, s. 134.

15 Przykładowo podczas powstania w Panonii w roku 6 n.e., czy po klęsce w Lesie Teutoburskim w roku 9 n.e.

16 W przypadku marynarzy floty stacjonującej w Rawennie i Misenum, z których za panowania Nerona sformowano legiony I i II Adiutrix, obywatelstwo rzymskie zostało nadane legionistom dopiero przez kolejnych cesarzy: odpowiednio Galbę i Wespazjana. Zob. A. Krawczuk, op. cit., s. 137 i n.; H.M.D. Parker, The Roman legions, Chicago 1980, s. 170.

17 Przede wszystkim ograniczenie kosztów podróży rekruta. Zob. H.M.D. Parker, op. cit., s. $160,171$.

18 H.M.D. Parker, op. cit., s. 182; P.A. Brunt, Roman Imperial Themes, Oxford 1990, s. 194; autor nadmienia, że taka praktyka była stosowana także na wschodnich obszarach Cesarstwa, gdzie legiony mogły od momentu sformowania składać się w większości z obcokrajowców (s. 198).

19 H.M.D. Parker, op. cit., s. 171.

20 Ibidem. 
chodziło z Italii, Galii lub Afryki, natomiast 53 - z Azji Mniejszej, Syrii i Egiptu (w tym: 29 z Azji Mniejszej, głównie z Galacji, 24 z Syrii i Egiptu) ${ }^{21}$. W czasach panowania dynastii flawijskiej proces rekrutacji żołnierzy z obszarów prowincji uległ nasileniu - inskrypcja datowana na ten okres poświadcza, że najwięcej rekrutów mogło pochodzić z Azji Mniejszej i Egiptu ${ }^{22}$. Za panowania Hadriana te proporcje musiały być podobne. Legio III Cyrenaica w tym czasie posiadała w swoich szeregach pewną liczbę żołnierzy rekrutowanych $\mathrm{z}$ obszarów greckojęzycznych i Egiptu ${ }^{23}$. Część strat poniesionych podczas walk jeszcze pod rozkazami Trajana w Arabii i Syrii w latach 115-116 musiała uzupełniać z lokalnych źróde ${ }^{24}$. Z kolei legion XXII Dejotariański żołnierzy posługujących się greką jako językiem rodzimym miał w swoich szeregach już od momentu sformowania. Jego geneza sięga okresu wojen domowych w okresie schyłkowej Republiki. Król Galacji Dejotar Filoromajos powołał „legion” wzorowany na rzymskim w celu wspomożenia oddziałów Pompejusza, a potem Cezara. Po włączeniu klienckiej Galacji do cesarstwa w 25 r. p.n.e. „legion” Dejotara znalazł się w strukturze armii rzymskiej z najwyższą wówczas numeracją XXII ${ }^{25}$. W tym czasie znacząca część jego żołnierzy (około 40\%) była Galatami. Proporcje te, zdaniem R. Alstona, mogły się utrzymywać przez pewien $\mathrm{czas}^{26}$. Być może ze względu na swoją historię i tradycję przyciągał greckojęzycznych rekrutów ${ }^{27}$. Niestety, ubogi materiał epigraficzny nie pozwala na bliższe poznanie składu etnicznego tej jednostki.

Mimo iż kopia listu została rozpowszechniona w obozie legionów, pozostaje otwartym pytanie, czy regulacja zawarta w treści mogła obejmować wszystkich żołnierzy posiadających obywatelstwo rzymskie, nie tylko legionistów, ale także służących w auxilia (w których niekiedy służyli także obywatele). Brian

21 Ibidem, s. 182

22 R. Haensch, The Roman Army in Egypt, w: Ch. Riggs (ed.), The Oxford Handbook of Roman Egypt, Oxford 2012, s. 72.

23 Odnośnie do wzmianki o egipskim legioniście służącym w legionie III zob. J.F. Gilliam, An Egyptian cohort..., s. 95 przyp. 18.

24 R. Alston, The ties that bind: soldiers and societes, w: A. Goldsworthy, I. Haynes (eds.), The Roman Army as a Community, Portsmouth 1999, s. 187.

25 L.F.J. Keppie, The History and Disappearance of the legion XXII Deiotariana, w: L. Keppie, Legions and veterans. Roman Army papers 1971-2000, Stuttgart 2000, s. 225-226; B. Campbell, War and Society in Imperial Rome 31 BC-AD 284, London-New York 2002, s. 49.

26 R. Alston, Soldier and Society in Roman Egypt. A social history, London-New York 1995, S. 30,42 .

27 W opinii R. Alstona okoliczności powstania legio XXII mogły zachęcać rekrutów pochodzących z Azji Mniejszej do zaciągania się w jego szeregi, R. Alston, Soldier and Society..., s. 50. 
Campbell przypuszcza, że przywilej był wydany w interesie obywateli rzymskich służących we wszystkich jednostkach armii rzymskiej, nie tylko we wspomnianych dwóch legionach ${ }^{28}$. Zdaniem S. Phang mógł objąć także wszystkich weteranów ${ }^{29}$.

Treść listu Hadriana ma ścisły związek z obowiązującą w okresie wczesnego cesarstwa (od panowania Oktawiana Augusta do Septymiusza Sewera) zasadą, że żołnierz nie może zawrzeć pełnoprawnego małżeństwa (matrimonium iustum $)^{30}$. Wśród różnorakich powodów wprowadzenia tej regulacji wymieniano troskę o zachowanie żołnierskiej karności, utrzymanie spójności legionu jako zwartej społeczności czy wreszcie kwestionowanie możliwości utrzymania lub kontynuowania zawartego już związku małżeńskiego wobec znacznego wydłużenia czasu służby wojskowej. Bez wątpienia niechętnie patrzono na trwałe i stabilne związki żołnierzy z kobietami, obawiając się negatywnego ich wpływu na karność i zaangażowanie w służbę wojskową ${ }^{31}$.

Mimo tego ograniczenia żołnierze często wchodzili w związki zarówno z obywatelkami rzymskimi ${ }^{32}$, jak i peregrynkami pochodzącymi ze społeczności lokalnych, a nawet niewolnicami. Jakkolwiek z treści listu Hadriana wynika, że takie postępowanie było uważane za czyn naruszający disciplina militaris, władze przymykały oko na takie praktyki ${ }^{33}$. Można nawet uznać, w świetle skali

28 B. Campbell, The marriage of soldiers under the Empire, JRS 1978/LXVIII, s. 158.

29 S.E. Phang, The Marriage of Roman Soldiers..., s. 39.

30 Dotyczyło to żołnierzy wszystkich jednostek armii, zarówno legionistów, jak i auxiliares mających już nadane obywatelstwo rzymskie, zob. S.E. Phang, The Marriage of Roman Soldiers..., s. 29. Odnośnie do dyskusji nt. zakazu małżeństw w źródłach jurydycznych, zob. S.E. Phang, The Marriage of Roman Soldiers..., s. 86 i n., tamże o zakazie s. 115 i n.; zob. także, B. Campbell, The marriage..., s. 153-166.

31 Te obawy można uznać za całkowicie uzasadnione. Władze starały się ograniczać aktywność żołnierzy, która mogłaby odciągnąć ich od służby i osłabiać morale. Z tego powodu m.in. zakazywano żołnierzowi kupować nieruchomości rolne w prowincji, w której służył podczas wojny [...] scilicet ne studio culturae militia sua avocentur [...] (D. 49.16.13). Podobne obiekcje mogły być związane z życiem rodzinnym żołnierzy.

32 Zob. chociażby przypadek żołnierza Longinusa, obywatela rzymskiego związanego z obywatelką rzymską. Prefekt Egiptu odmówił uznania ich potomstwa jako legalnego. Szerzej o tym przypadku pisze S.E. Phang, The Marriage of Roman Soldiers..., s. 25-26.

33 Zdaniem S. Phang, złamanie ,zakazu” zawierania małżeństw nie było rozumiane jako naruszenie dyscypliny wojskowej sensu stricto, zakaz ten bowiem nie miał na celu wzmocnienia karności żołnierza, ale „safeguarded the masculine habitus of soldiers” (S.E. Phang, Roman Military Service. Ideologies of Discipline in the Late Republic and Early Principate, Cambridge 2008, s. 92), przy czym habitus winien być rozumiany jako właściwa żołnierska postawa. Habitus nie był więc tym samym co dyscyplina, aczkolwiek być z nią ściśle związany (ibidem, s. 7). Zatem troszcząc się o zachowanie żołnierskiego ducha (dla którego małżeństwo mogło 
zjawiska, że milcząco uznawano takie faktyczne związki, zadowalając się sankcją w postaci braku jakichkolwiek prawnych skutków ich istnienia. Konsekwencje dotykały zwłaszcza dzieci żołnierza ${ }^{34}$, które uzyskiwały status pozamałżeńskich i jako takie pozbawione były na gruncie prawa prywatnego uprawnień majątkowych oraz możliwości nabycia spadku po żołnierzu-obywatelu.

Już od połowy I w. zaczęto usuwać niekorzystne skutki ograniczenia swobody zawierania małżeństw poprzez nadawanie żołnierzowi conubium cum uxoribus i obywatelstwa rzymskiego dzieciom zrodzonym podczas służby. Następowało to z okazji missio honesta i nabycia statusu weterana ${ }^{35}$. Liczba dzieci zrodzonych z żołnierskich związków sukcesywnie rosła; w drugiej połowie II w. wielu rekrutów podawało jako miejsce urodzenia obóz wojskowy (origo castris). Datowane na 161 r. dokumenty źródłowe, związane z rekrutacją pokazują, że na 30 rekrutów $1 / 3$ to potomkowie żołnierzy urodzeni w castra (liberi ex castris $)^{36}$.

Łagodzenie skutków prawnych zakazu małżeństwa obejmowało także aspekty prawa spadkowego. Liberi illegitimi pochodzący ze związku żołnierza i jego partnerki, choć pozbawieni testamenti factio passiva, zostali dopuszczeni do dziedziczenia po ojcu na mocy testamentu żołnierskiego. Pozwalano żołnierzom także, jak przekazuje Gajusz, ustanawiać dziedzicami peregrynów i Latynów Juniańskich jako heredes extranei ${ }^{37}$. Za życia Ulpiana, to jest na przełomie II i III w., możność powołania testamentem żołnierskim do spadku osoby pozbawionej testamenti factio passiva była, jak się wydaje, regułą ${ }^{38} . \mathrm{Ku}$ takiemu ustępstwu skłaniano się jednak znacznie wcześniej. Już w 115 r. prefekt Egiptu Rutyliusz Lupus, przyznając, że syn żołnierza Juliusza Marcjalisa

stanowić pewne zagrożenie, przytępiając chociażby agresywne instynkty niezbędne na polu walki), władze rzymskie przymykały oko na mniej stabilne związki żołnierzy z kobietami, nie traktując tego na równi z naruszeniem karności.

34 Kontrowersyjny wydaje się być status dzieci zrodzonych z matrimonium iustum, które zostało zawarte przed wstąpieniem żołnierza na służbę wojskową. Jeśli dziecko urodziło się w małżeństwie zanim obywatel zaczął odbywać służbę, było jego pełnoprawnym potomkiem, natomiast dziecka urodzonego już po wstąpieniu na służbę nie uznawano za legalne, z uwagi na fakt, że małżeństwo, jak sądzą niektórzy badacze, ulegało rozwiązaniu z uwagi na czas trwania służby wojskowej. Zob. B. Campbell, The marriage..., s. 155 i n.

35 Nadawanie obywatelstwa dzieciom żołnierza praktykowano tylko przez relatywnie krótki okres, najdalej do pierwszej połowy II w. n.e.

36 H.M.D. Parker, op. cit., s. 184.

37 Co w przypadku innych, niż żołnierze, testatorów byłoby nieskuteczne. Zob. Gai. 2.110.

38 D. 29.1.13.2 (Et deportati et fere omnes, qui testementi factionem non habent a milite heredes institui possunt). 
zrodzony podczas służby nie może być traktowany jako filius legitimus, dopuścił mimo to możliwość ustanowienia go spadkobiercą ex testamento ${ }^{39}$. Tym samym uwzględniano potrzeby żołnierzy wynikające zarówno z natury iniustum matrimonium, jak i będące konsekwencją etnicznego składu armii rzymskiej. W konsekwencji żołnierz mógł powołać do spadkobrania peregrynkę, z którą żył w związku, zrodzone $\mathrm{w}$ nim potomstwo, a nawet - jeśli przed wstąpieniem do legionu sam był peregrynem - swoich nieposiadających obywatelstwa rzymskiego krewnych. Przyzwolenie na powołanie testamentem do dziedziczenia Latynów Juniańskich mogło uwzględniać fakt, że wiele życiowych partnerek żołnierzy było niewolnicami wyzwolonymi nieformalnie $\mathrm{w}$ trakcie trwania związku (to samo mogło dotyczyć ich potomstwa zrodzonego w niewoli i potem także wyzwolonego). Powoływanie do spadku wspomnianych kategorii spadkobierców miało miejsce zwłaszcza w przypadku testamentów sporządzanych na terenie Egiptu ${ }^{40}$. Odzwierciedla to przekrój społeczny rodziny żołnierza, w której „uxor” najczęściej była peregrynką albo niewolnicą wyzwalaną na jakimś etapie istnienia związku, a dzieci miały status matki. W ten sposób poszerzono krąg spadkobierców żołnierzy, który w przeciwnym razie mógłby zawężać się jedynie do posiadających obywatelstwo rzymskie commilitones.

Dzieci żołnierskie zrodzone w nieformalnych związkach udowadniały swoje pochodzenie na podstawie testatio liberorum uzyskiwanej przez ojców po ich urodzeniu. Wielu żołnierzy sporządzało odpowiednie świadectwo w postaci woskowej tabliczki, zawierającej sformułowanie propter districtionem militiae. Wskazywało ono na świadomość surowych konsekwencji zakazu małżeństw dla pozycji prawnej potomstwa. Testationes sporządzano z uwagi na późniejsze potencjalne korzyści - możliwość nabycia obywatelstwa dla potomstwa (gł. w przypadku żołnierzy auxilia) i prawdopodobnie w celu późniejszego ubiegania się o objęcie spadku przez dzieci powołane przez żołnierza w testamencie ${ }^{41}$. Jednak było to rozwiązanie połowiczne, jako że dawało pozamałżeńskim dzieciom żołnierzy możliwość spadkobrania jedynie w przypadku dziedziczenia testamentowego - i to jedynie gdyby sporządzono testament żołnierski. Ten zaś był ważny jedynie przez rok, licząc od missio honesta lub missio causaria żołnierza, który go sporządził ${ }^{42}$. Po tym okresie możliwość dziedziczenia przez liberi illegitimi

39 FIRA III. 19 b) (Non poterat quidem Martialis dum militabat legitimum filium habere, heredem autem eum iure scripsit). Zob. E. Sander, Das Recht des Römischen Soldaten, Rheinisches Museum für Philologie, Neue Folge, 1958/101. 2, s. 157.

40 Zob. przykłady podane przez S.E. Phang, The Marriage of Roman Soldiers..., s. 218 i n.

41 Ibidem, s. $41 \mathrm{i} \mathrm{n.}$

42 Zwolnienia honorowego z powodu odsłużenia pełnego okresu lub z powodów zdrowotnych. 
żołnierzy odpadała. Wyjściem z tej sytuacji było nabycie przez dzieci żołnierza obywatelstwa rzymskiego wraz ze wszystkimi wynikającymi z tego prawami. Takie rozwiązanie pojawiło się z pewnością już pod koniec I w. n.e., na mocy przywileju nadanego edyktem przez cesarza Domicjana ${ }^{43}$. Zdaniem S. Phang nabycie obywatelstwa przez liberi żołnierza nie musiało automatycznie oznaczać ich wejścia pod patria potestas ani tym bardziej nabycia praw spadkowych ${ }^{44}$. Niezależnie od powyższego, nie ma całkowitej pewności, czy to rozwiązanie mogło być brane pod uwagę w przypadku dzieci żołnierzy legionów III i XXII. Nie można z całą pewnością stwierdzić, czy edykt Domicjana miał charakter generalny i obejmował wszystkich żołnierzy armii rzymskiej, w tym floty i auxiliares, czy też dotyczył tylko niektórych legionistów. Ponadto pod koniec I w. pojawia się tendencja do ograniczania nadań obywatelstwa dzieciom legionistów poczętym w trakcie służby wojskowej. Przywilej nadany przez Domicjana mógł zostać cofnięty albo przez Nerwę, albo Trajana. Z pewnością nie nadawano obywatelstwa dzieciom legionistów i auxiliares za panowania Antonina Piusa (prawdopodobnie od 140 r.). Liberi ex castris mogli je uzyskać, wstępując, wzorem swoich ojców, do służby wojskowej ${ }^{45}$.

Brak testamentum militare skutkował dziedziczeniem ab intestato - które z oczywistych względów wykluczało liberi ex castris, co zresztą wyraźnie wynika z treści listu Hadriana (,[...] zatem nie są prawnymi spadkobiercami

${ }_{43}$ Więcej o edykcie i jego znaczeniu w: A. Świętoń, K. Tadajczyk, 'Edictum Domitiani de privilegiis veteranorum'. Edykt cesarza Domicjana o przywilejach weteranów, Zeszyty Prawnicze 2014/14.4, s. 5 i n.

44 S.E. Phang, The Marriage of Roman Soldiers..., s. 308 i n. Autorka, powołując się m.in. na teksty Gajusza, wskazuje, że w I połowie II w. n.e. wprowadzenie dzieci pod patria potestas nie musiało być ipso iure skutkiem nabycia przez dziecko obywatelstwa rzymskiego. Taka konkluzja może wynikać z lektury tekstu Gajusza, w którym wspomina on o edykcie Hadriana regulującym kwestię wejścia pod patria potestas dzieci peregryna, który nabył na siebie i dla potomstwa obywatelstwo rzymskie (Gai. 1.93). W tym przypadku dzieci mogą znaleźć się pod władzą ojca nie dzięki nabyciu przez nie civitas Romana, ale na skutek decyzji podjętej przez cesarza. $Z$ drugiej strony prawo przewidywało wejście dzieci pod władzę ojca na skutek nabycia przez nie obywatelstwa (np. w przypadku dzieci obywatela rzymskiego i peregrynki - Gai. 1.67, obywatelki rzymskiej i peregryna - Gai. 1.68, Latyna i obywatelki rzymskiej Gai. 1.66). Wzmianka Gajusza o przywilejach nadawanych niektórym weteranom-obywatelom rzymskim, przyznającym im conubium z Latynkami i peregrynkami, które post missionem pojmą za żony jako pierwsze (Gai. 1.57) nie wyjaśnia wiele, ponieważ urodzenie dziecka następowało już w iustum matrimonium ze wszystkimi tego skutkami (w tym: nabyciem przez potomstwo obywatelstwa rzymskiego i wejście pod władzę ojcowską).

45 Zob. A. Świętoń, K. Tadajczyk, op. cit., s. 16 i n., także S. Link, Konzepte der Privilegierung römischer Veteranen, Stuttgart 1999, s. 95 i n. 
swoich ojców ci, których spłodzono podczas służby wojskowej [...]”), i pokrywa się ze stanowiskiem wspomnianego powyżej prefekta Egiptu Rutyliusza Lupusa ([...] Non poterat quidem Martialis dum militabat legitimum filium habere [...]). Jednakże, jak wynika z dalszej treści listu, cesarz postanowił rozszerzyć ochronę interesów spadkowych dzieci żołnierskich z nieprawego łoża także na dziedziczenie ab intestato. Na mocy udzielonego beneficium mogły ubiegać się o bonorum possessio w klasie unde cognati, o ile wcześniej pretor nie zaoferował bonorum possessio ewentualnemu legalnemu potomstwu żołnierza zaliczanemu do klasy unde liberi ${ }^{46}$, albo - w dalszej kolejności - agnatom powołanym do dziedziczenia zgodnie z porządkiem Ustawy XII tablic (unde legitimi). Ubiegający się o bonorum possessio potomek żołnierza musiał udowodnić swoje pochodzenie - i czynił to za pomocą wspomnianej powyżej testatio liberorum. Po nadaniu przez Hadriana omawianego beneficium sporządzanie testationes przez żołnierzy mogło zatem stanowić formę deklaracji uznania swoich liberi naturales jako potencjalnych spadkobierców ${ }^{47}$.

Epistula Hadriana nie wprowadziła istotnych zmian w statusie prawnym potomstwa żołnierzy. Cesarz podtrzymał stanowisko swoich poprzedników w kwestii illegitimatio i mimo zajęcia łagodnego stanowiska nie wypowiedział się na temat zasadności istnienia zakazu zawierania małżeństw przez żołnierzy - znacznie jednak polepszył sytuację ich potomstwa na gruncie prawa spadkowego. Do chwili ogłoszenia przywileju liberi ex castris byli uwzględniani w dziedziczeniu tylko w przypadku, gdyby ustanowiono ich dziedzicami w testamencie żołnierskim, co stanowiło niezadowalające rozwiązanie, z uwagi na wspomniany już powyżej czas jego obowiązywania. Tracił on ważność rok po zwolnieniu z wojska, a w przypadku missio ignominiosa ${ }^{48} \mathrm{z}$ chwilą usunięcia z szeregów.

46 Mowa np. o potomstwie, które zrodziło się z matrimonium iustum zawartego przez żołnierza przed wstąpieniem na służbę albo po jej zakończeniu.

47 J.F. Gilliam, Some Roman elements in Roman Egypt, w: J.F. Gilliam, Roman Army Papers, Amsterdam 1986, s. 412-413.

48 Zwolnienia np. z powodu popełnienia przez żołnierza przestępstwa (zwyczajnego albo wojskowego) lub próby samobójczej. Zob. D. 49.16.3.3 oraz D. 49.16.6.7. Samobójstwom żołnierzy poświęcił niewielką część swojej pracy na temat samobójstwa w prawie rzymskim A. Wacke. Ograniczył się on jednak jedynie do przytoczenia i opisania podstawowych źródeł, nie zagłębiając się dostatecznie w ich analizę (A. Wacke, Estudios de derecho Romano y moderno. En cuatro idiomas, Madrid 1996, s. 540-541). Nieco więcej uwagi poświęciła temu zagadnieniu M.R. De Pascale w pracy Sul suicidio del miles, Labeo 1985/31, s. 57-61. Kwestię samobójstw dokonywanych przez żołnierzy omówił także pod kątem zagadnienia infamii B. Sitek, Infamia w ustawodawstwie cesarzy rzymskich, Olsztyn 2003, s. 177-179. 
Możliwość powołania do dziedziczenia w klasie unde cognati wzmacniała ich pozycję. Dziecko żołnierskie, bez względu na jego status civitatis, zyskiwało testamenti factio passiva także na gruncie dziedziczenia ab intestato. Odpadało ryzyko związane z niepozostawieniem testamentu żołnierskiego przez ojca albo jego nieważnością, która mogła wynikać np. z budzącego wątpliwości ustanowienia dziedzica ${ }^{49}$. Jako że postanowieniami zawartymi w epistula objęto prawdopodobnie także weteranów, ochrona praw spadkowych liberi ex castris trwałą również po zakończeniu przez ich ojców służby wojskowej. Może to oznaczać, że albo w omawianym okresie nie obowiązywał wspomniany przywilej Domicjana i, przynajmniej w odniesieniu do legionistów, missio honesta nie wywoływała skutku w postaci nadania civitas Romana potomstwu, albo przypadki takie należały do rzadkości. Potwierdzać się może teza S. Phang na temat braku zależności pomiędzy nabyciem przez liberi ex castrum obywatelstwa rzymskiego a ich wprowadzeniem pod patria potestas ojca i nabyciem praw spadkowych w grupie heredes sui ${ }^{50}$.

Hadrian uniezależnił dziedziczenie od nabycia przez potomstwo obywatelstwa rzymskiego i wejścia pod patria potestas (choć w przypadku braku węzła agnacyjnego sytuacja dzieci żołnierskich na gruncie dziedziczenia ex testamento była niepewna $\mathrm{w}$ związku z faktem, że po roku od zakończenia służby nie było już możliwości powołania do dziedziczenia peregryna, jaką dawało testamentum militis). Należało też liczyć się z prawdopodobieństwem pojawienia się potomstwa zrodzonego z matrimonium iustum zawartego już po missio honesta. Jednakże, nawet przy uwzględnieniu takich niedogodności beneficium nadane przez Hadriana było znaczącym krokiem naprzód we wzmacnianiu ochrony praw spadkowych liberi ex castris. Wpisywało się także w szerszą politykę prowadzoną m.in. przez Trajana i Hadriana, zmierzającą do polepszania sytuacji prawnej żołnierzy (m.in. poprzez rozwój instytucji testamentu żołnierskiego i peculium castrense $)^{51}$.

Ślady uregulowania Hadriana można odnaleźć w pochodzącej z połowy II w. (datowanej na okres panowania Antonina Piusa) kompilacji praw wyda-

49 Takie sytuacje mogły być częste wśród żołnierzy z reguły niedostrzegających wymogu precyzyjnego i jasnego wskazania dziedzica (nawet mimo braku konieczności zachowania przewidzianej prawem formy). O niedociągnięciach tego rodzaju w przypadku testamentum militis wzmiankuje jurysta Florus (D. 29.1.24).

$50 \quad$ Patrz przyp. 44.

51 O wkładzie Trajana w rozwój instytucji testamentu żołnierskiego wspomina Ulpian (D. 29.1.1pr). Zob. też V. Scarano Ussani, Il , testamentum militis” nell'età di Nerva e Traiano, w: V Giuffrè (ed.), Sodalitas. Scritti in onore di Antonio Guarino, t. 3, Napoli 1984, s. 1383-1395. 
nych w Egipcie, obejmujących swoim obowiązywaniem także obywateli rzymskich (Gnomon Idios Logos) ${ }^{52}$. Zgodnie z treścią paragrafu 35 Gnomonu dzieci i krewni żołnierzy zmarłych bez testamentu mogli po nich dziedziczyćc ${ }^{53}$, jeśli pochodzili z tego samego rodu (gens, $\gamma \varepsilon ́ v o \zeta)$. Zdaniem W. Uxkull-Gyllenbanda świadczy to o szerokim stosowaniu w praktyce rozwiązania ustanowionego przez Hadriana ${ }^{54}$.

Powodów, dla których Hadrian zdecydował się przyznać liberi ex castris prawo dziedziczenia po ojcu w klasie unde cognati, można się doszukiwać w łagodnym usposobieniu władcy i umiejętności budowania relacji z poddanymi ${ }^{55}$. Sformułowania użyte w tekście epistula wskazują na chęć złagodzenia surowych regulacji prawnych ${ }^{56}$. Hadrian, uznając potrzebę utrzymania żołnierzy w karności, jednocześnie sygnalizował, że nie jest mu obca troska o ich los i los ich najbliższych krewnych. Filantropia i humanitas przenikają wiele rozwiązań prawnych wprowadzonych w życie za panowania cesarza, uwzględniających voluntas i aequitas ${ }^{57}$. Można tu przywołać chociażby próbę łagodniejszej interpretacji Senatusconsultum Silanianum ${ }^{58}$, poprawę losu sprzedawanych niewolnic poprzez wprowadzenie ściślejszej kontroli umów kupna-sprzedaży $\mathrm{z}$ dodaną klauzulą ne prostitutatur (szczególnie takich, w których jednym z kontrahentów był stręczyciel ${ }^{59}$ ), ustanowienie zakazu sprzedaży niewolników do

52 Gnomon Idios logos został skompilowany za panowania Oktawiana Augusta, jednakże z tego okresu zachowały się jedynie fragmenty, treść jego - jak wynika z preambuły zachowanej w egzemplarzu z II w. n.e. - była uzupełniania o nowe regulacje obowiązujące w prawie rzymskim. Przytoczony fragment pochodzi z egzemplarza z ok. 149 r. Zob. J.G. Keenan, J.G. Manning, U. Yiftach-Firanko (eds.), Law and Legal Practice in Egypt from Alexander to the Arab Conquest, Cambridge 2014, s. 72.

53 Der Gnomon de Idios Logos. Band 1: der Text, (= ̈̈gyptische Urkunden aus den Staatlichen Museen zu Berlin. Griechische Urkunden. Bd. 5) oprac. W. Schubart, Berlin 1919, s. 19.

54 Der Gnomon des Idios Logos. Band 2: Kommentar (= Ägyptische Urkunden aus den Staatlichen Museen zu Berlin. Griechische Urkunden. Bd. 5), oprac. Woldemar Graf Uxkull-Gyllenband, Berlin 1934, s. 45.

55 Jeśli wierzyć antycznemu historiografowi, charakter cesarza był mieszaniną łagodności i okrucieństwa (De Vita Hadriani 14.11). Pomijając kwestię antycznego toposu władcy, z regulacji prawnych, pozostawionych przez Hadriana, przebija zdecydowanie ta pierwsza cecha.

56 A. Palma, Benignior interpretatio. Benignitas nella giurisprudenza e nella normazione da Adriano ai Severi, Torino 1997, s. 48.

57 R.A. Bauman, Lawyers and Politics in the Early Roman Empire. A study of relations between the Roman jurists and the emperors from Augustus to Hadrian, München 1989, s. 236.

58 Zob. K. Amielańczyk, Głos cesarza Hadriana w sprawie S.C. Silanianum, Zeszyty Prawnicze 2006/6.1, s. 16 i n.

59 K. Amielańczyk, Reskrypt cesarza Hadriana o zakazie sprzedaży niewolnic stręczycielom i niewolników właścicielom szkół gladiatorskich, w: H. Kowalski, M. Kuryłowicz (red.), 
szkół gladiatorskich, ograniczenie ius vitae ac necis właścicieli niewolników ${ }^{60}$, autorstwo projektu senatus consultum polepszającego sytuację prawną syna zrodzonego z obywatelki rzymskiej i peregryna ${ }^{61}$. Reformował prawo karne, rozbudowując m.in. zasady odpowiedzialności subiektywnej ${ }^{62}$. Cesarz, miłośnik greckiej kultury i idei humanitas, jak pisze Krzysztof Amielańczyk, „nie tracił z pola widzenia losu pojedynczego człowieka", brał pod uwagę względy humanitarne, a niekiedy stawiał je przed interesem publicznym ${ }^{63}$.

Owa łagodność i humanitaryzm Hadriana, którą treść epistula wyraźnie przeciwstawia surowości postanowień poprzednich cesarzy, współgra z jego podejściem do spraw żołnierskich. Hadrian, podobnie jak jego poprzednik, dbał o utrzymanie dobrych relacji z żołnierzami i armią jako całością. Rozumiał potrzebę utrzymania karności wśród żołnierzy. Poddał ich surowej dyscyplinie, aby zapobiec ewentualnym buntom, zanim jeszcze został cesarzem, dowodząc jako legat legionami w dolnej Panonii ${ }^{64}$. Starał się jednak utrzymywać stały kontakt z prostymi żołnierzami, świecił im przykładem, nosząc się tak jak oni i spożywając podobne, jak oni, posiłki, ograniczał też zbytek w obozie ${ }^{65}$. Jego troskę o morale armii pokazują inspekcje legionów - sztandarowym przykładem jest wizytacja stacjonującego w Lambaesis legionu III Augusta przeprowadzona w 128 r., po której zachowały się fragmenty mowy cesarza wygłoszonej do legionistów, jeźdźców i auxiliares ${ }^{66}$. Hadrian kontynuował tym samym politykę swojego poprzednika, wzmacniając disciplina militaris i jednocześnie budując

Contra leges et bonos mores. Przestępstwa obyczajowe w starożytnej Grecji i Rzymie, Lublin 2005, s. 15 i n. Zob. także A. Sokala, The effectiveness of the "ne prostituatur" clauses in Roman law, EOS 1993/81, s. 97-100. s. 254

63 Ibidem. Odnośnie do dyskusji na temat idei humanitaryzmu obecnej w prawodawstwie Hadriana, zob. H. Hübner, Zur Rechtspolitik Kaiser Hadrians, w: H. Hübner, E. Klingmüller, A. Wacke (Red.), Festschrift für Erwin Seidl zum 70. Geburtstag, Köln 1975, s. 61-74. und miles. Studien zum Bindungs- und Nahverhätnis ven Kaiser und Soldat im 1. Und 2. Jahrhundert n. Chr., Zürich-New York 2003, s. 97 i n. 
propagandowy przekaz o istnieniu szczególnych więzi łączących pryncepsa $\mathrm{z}$ armią, tak doskonale zobrazowany w scenach zdobiących Kolumnę Trajana ${ }^{67}$.

Rozumiejąc potrzebę poddania żołnierzy surowym wymogom disciplina, starał się łagodzić wszelkie związane z nią dolegliwości. Rozdawał nagrody oraz awanse, aby łatwiej znoszono zbytnią niekiedy surowość ${ }^{68}$. Humanitas widoczna jest $\mathrm{w}$ regulacjach Hadriana dotyczących karania żołnierzy, którzy popełnili crimen militare albo zaniedbali swoje obowiązki - dotyczących np. postępowania wobec żołnierzy zbiegłych do wroga (transfugae) ${ }^{69}$, odpowiedzialności żołnierzy, którzy podjęli próbę samobójczą lub dokonali samookaleczenia pod wpływem m.in. bólu, choroby, taedium vitae ${ }^{70}$. Hadrian nakazał też uwzględniać stopień zawinienia żołnierzy, którym uciekł strzeżony przez nich więzień, i stosować odpowiednie kary ${ }^{71}$, ograniczając karę śmierci jedynie do przypadku, w którym wina strażnika była nadmierna ${ }^{72}$.

Łagodność natury cesarza, podkreślana w tekście epistula, nie musi być jedynym wyjaśnieniem decyzji podjętej w 119 r. Mógł istnieć jeszcze jeden stricte polityczny powód nadania beneficium .

Hadrian obejmował rządy w niekorzystnym dla siebie momencie. Wschodnią częścią cesarstwa wstrząsały antyrzymskie bunty (m.in. w Egipcie, Libii, Mauretanii, Palestynie), zaś wojna z Partami rozpoczęta w 113 r. przez Trajana nie była jeszcze w pełni rozstrzygnięta. Podjęte przez Hadriana działania miały z początku zachowawczy charakter - często oznaczały rezygnację ze świeżych nabytków terytorialnych. Cesarz był zmuszony postępować ostrożnie z uwagi na obecność w swoim otoczeniu wielu politycznych przeciwników jego pano-

67 Na temat znaczenia płaskorzeźb Kolumny Trajana w kontekście imperialnej propagandy zob. m.in. E. Condurachi, Riflessi della propaganda politica e della strategia militare sui rilievi della Colonna di Traiano, w: E. Condurachi (ed.), L'Esame Storico-artistico della Colonna Traiana. Colloquio italo-romano. Roma 25 Ottobre 1978, Roma 1982, s. 7-19; F. Coarelli, La collonna Traiana, Roma 1999; G.M. Koeppel, The Column of Trajan: Narrative Technique and the Image of the Emperor, w: P.A. Stadter, L. Van der Stockt (eds.), Sage and emperor: Plutarch, Greek intellectuals, and Roman power in the time of Trajan (98-117 A.D.), Leuven 2002, s. 245-258.

68 De vita Hadriani 10.2 (multos praemiis, nonnullos honoribus donans).

${ }_{69}$ D. 49.16.5.6, D. 49.16.5.8.

70 D. 49.16.6.7. W odniesieniu do samobójstw żołnierzy zob. przyp. 48. Kwestię taedium vitae jako okoliczności usprawiedliwiającej samobójstwo lub próbę samobójczą poruszył M. Kuryłowicz, Taedium vitae w rzymskim prawie karnym, w: H. Kowalski, M. Kuryłowicz (red.), Contra leges et bonos mores. Przestęstwa obyczajowe w starożytnej Grecji i Rzymie, Lublin 2005, s. 189-193.

71 D. 48.3 .12 .

72 K. Amielańczyk, Rzymskie prawo karne..., s. 223. 
wania. Strategiczne decyzje o charakterze defensywnym (wycofanie się z Mezopotamii i Armenii) mogły zrazić do niego część żołnierzy biorących udział w walkach ${ }^{73}$. Autor De vita Hadriani wspomina o wielkiej skłonności do łagodności, jaką Hadrian okazywał tuż po objęciu rządów ${ }^{74}$. Unikał otwartej konfrontacji z politycznymi przeciwnikami, starał się zdobyć lojalność armii - żołnierze $\mathrm{z}$ okazji auspicia imperii otrzymali donativa w podwojonej wysokości ${ }^{75}$.

Krótko po objęciu przez Hadriana władzy (w 118 r.) został ujawniony skierowany przeciwko niemu tzw. „spisek czterech konsularów”, co wymusiło na cesarzu jesienią tegoż roku konieczność szybkiego powrotu znad Dunaju do Rzymu. Okoliczności zawiązania sprzysiężenia nie są jasne. Autor De vita Hadriani enigmatycznie wspomina tylko o przywódcy spisku Gajuszu Awidiuszu Nigrynie ${ }^{76}$ i współdziałających z nim Luzjuszu Kwietusie ${ }^{77}$, Aulusie Korneliuszu Palmie ${ }^{78}$ i Lucjuszu Publiliuszu Celsusie ${ }^{79}$, chociaż sprzysiężenie miało znacznie szerszy zasięg $^{80}$. Zgładzono Nigryna i trzech pozostałych konsularów, jednak to wydarzenie, jak i sama ranga głównych spiskowców (ludzi powiązanych z Trajanem, zasłużonych w prowadzonych przez niego wojnach i wyróżnianych przez niego wielokrotnie ${ }^{81}$ ) musiały uświadomić Hadrianowi, że jego pozycja jest chwiejna.

„Spisek czterech konsularów” mógł osłabić legitymację Hadriana także w oczach armii. Warto nadmienić, że niektórzy ze zgładzonych spiskowców

73 Zdaniem C. Wellsa mogły się one przyczynić do zawiązania „spisku czterech konsularów” (p. poniżej), zob. C. Wells, Cesarstwo rzymskie, Warszawa 2005, s. 242. Zob. też A.R. Birley, Hadrian, Warszawa 1997, s. 150.

74 De vita Hadriani 5.5. (Tantum autem statim clementiae studium habuit...). Fragment wspominający o łagodności cesarza może być traktowany dwojako: albo jako zabieg propagandowy będący w istocie prezentacją jednej cechy będącej atrybutem władzy cesarskiej (H.W. Benario mówi w tym przypadku o sloganie, A commentary on the Vita Hadriani in the Historia Augusta, Michigan 1980, s. 63, zob. także J. Fündling, Kommentar zur Vita Hadriani der Historia Augusta, Bonn 2006, s. 417), albo maskować niepewność cesarza orientującego się w swojej nowej pozycji. Jak wspomniano powyżej, Hadrianowi zarzucano obłudę i zmienność charakteru, był na przemian okrutny i łagodny (De vita Hadriani 14.11).

77 Legat Judei w 117 r, konsul suffectus z 117 r. A. Degrassi, I Fasti Consolari..., s. 34; H.W. Benario, A commentary..., s. 65. W okresie poprzedzającym udział w spisku Kwietus został pozbawiony przez Hadriana dowodzenia nad sprzymierzoną jazdą mauryjską (De Vita Hadriani 5.8).

78 Konsul z lat 99 i 109. A. Degrassi, I Fasti Consolari..., s. 29 i 32.

79 Sprawował konsulat w 113 r., zob. A. Degrassi, I Fasti Consolari..., s. 33.

80 De vita Hadriani, 7.1.

81 A.R. Birley, op. cit., s. 137. 
byli znani żołnierzom - w tym także wchodzącym w skład legionu III Cyrenaica. Luzjusz Kwietus brał udział w kampanii partyjskiej Trajana. Lawrence Keppie sądzi, że mógł on mieć pod swoją komendą żołnierzy III legionu Cyrenajskiego (a przynajmniej żołnierzy wchodzących w skład vexillatio, która powróciła $\mathrm{z}$ frontu partyjskiego na przełomie lat 116 i 117 do Jerozolimy, aby tłumić powstanie żydowskie ${ }^{82}$ ). Wcześniej wydzielone oddziały legionu III Cyrenajskiego (a być może cały legion) były czasowo oddane pod rozkazy Korneliusza Palmy, gdy ów - jeszcze jako namiestnik Syrii - otrzymał zadanie podporządkowania Rzymowi Arabii ${ }^{83}$. Czy ogłaszając zawarty w epistula przywilej cesarz chciał polepszyć nadszarpnięty wizerunek w oczach żołnierzy? Na pewno podejmował inne działania mające osiągnąć ten cel. Emisja monet (sestertius) z legendą CONCORDIA EXERCITUUM za trzeciego konsulatu Hadriana (a więc w tym samym czasie, w którym ogłoszono omawiany przywilej) może być powiązana $z$ niedoszłym zamachem na życie cesarza i następującymi po nim zabiegami propagandowymi, mającymi umocnić pozycję cesarza $\mathrm{w}$ armii ${ }^{84}$. Trudno jednak odpowiedzieć na to pytanie jednoznacznie. $Z$ równym prawdopodobieństwem można przyjąć, że przywilej był odpowiedzią na oczekiwania żołnierzy, które cesarz poznał, dowodząc legionami jeszcze za życia Trajana. Mógł on uznać, że w obliczu kryzysu ogłoszenie przywileju przyniesie wymierne korzyści polityczne.

Epistula Hadriani stanowi interesujący przykład cesarskiego ustawodawstwa z pogranicza prawa prywatnego i spraw wojskowych. Jest też doskonałą ilustracją polityki, jaką pryncepsi prowadzili wobec armii, która w coraz większym stopniu stawała się gwarantem ich władzy. Jednak za jej wydaniem może stać coś więcej niż tylko troska o poprawność politycznych relacji z armią. Hadrian musiał być świadom wzrastającej liczby żołnierskich dzieci pozamałżeńskich jako konsekwencji utrzymywania zakazu zawierania małżeństw przez żołnierzy. W oczach żołnierzy, często żyjących w izolowanych społecznościach, dopuszczenie najbliższych krewnych, mimo uprzedniego

82 L.J.F. Keppie, The Legionary Garrison of Judaea under Hadrian, w: L. Keppie, Legions and veterans. Roman Army papers 1971-2000, Stuttgart 2000, s. 222. Artykuł pierwotnie opublikowany w Latomus 1973/32, s. 859-864.

83 P.-L. Gatier, La Legio III Cyrenaica..., s. 343, odnośnie do dyskusji o udziale III legionu w podboju Arabii, zob. P. Freeman, The annexation of Arabia and the imperial Grand Strategy, w: D.L. Kennedy (ed.), The Roman Army in the East, Ann Arbor 1996, s. 95 i n. (s. 91-118).

84 Zob. I. Luć, Hadrian's Military Coins. The Types COHORTES PRAETORIAE, EXERCITUS and DISCIPLINA AUGUSTI, w: E Dąbrowa, M. Dzielska, M. Salomon, S. Sprawski (red.), Hortus Historiae. Księga pamiatkowa ku czci profesora Józefa Wolskiego w setna rocznice urodzin, Kraków 2010, s. 367. 
braku testamenti factio passiva, do dziedziczenia po swoim ojcu mogło być postrzegane nie tylko jako przejaw humanitaryzmu, ale także zadośćuczynienie elementarnemu poczuciu sprawiedliwości.

\section{Bibliografia}

Alston Richard, Soldiers and society in Roman Egypt. A social history, London-New York 1995.

Alston Richard, The ties that bind: soldiers and societes, w: Adrian Goldsworthy, Ian Haynes (eds.), The Roman Army as a Community, Portsmouth 1999, s. 175-195.

Amielańczyk Krzysztof, Gtos cesarza Hadriana w sprawie S.C. Silanianum, Zeszyty Prawnicze 2006/6.1, s. 9-25.

Amielańczyk Krzysztof, Reskrypt cesarza Hadriana o zakazie sprzedaży niewolnic stręczycielom i niewolników właścicielom szkót gladiatorskich, w: Henryk Kowalski, Marek Kuryłowicz (red.), Contra leges et bonos mores. Przestęstwa obyczajowe w starożytnej Grecji i Rzymie, Lublin 2005, s. 9-23.

Amielańczyk Krzysztof, Rzymskie prawo karne w reskryptach cesarza Hadriana, Lublin 2006.

Bauman Richard. A., Lawyers and Politics in the Early Roman Empire. A study of relations between the Roman jurists and the emperors from Augustus to Hadrian, München 1989.

Benario Herbert W., A commentary on the Vita Hadriani in the Historia Augusta, Michigan 1980.

Birley Anthony R., Hadrian, Warszawa 1997.

Bishop Mike C., Handbook to Roman Legionary Fortresses, Barnsley 2012.

Brunt Peter A., Roman Imperial Themes, Oxford 1990.

Campbell Brian, The marriage of soldiers under the Empire, JRS LXVIII (1978), s. 153-166.

Campbell Brian, War and Society in Imperial Rome 31 BC-AD 284, London-New York 2002.

Coarelli Filippo, La collonna Traiana, Roma 1999.

Condurachi Emil, Riflessi della propaganda politica e della strategia militare sui rilievi della Colonna di Traiano, w: Emil Condurachi (ed.), L'Esame Storico-artistico della Colonna Traiana. Colloquio italo-romano. Roma 25 Ottobre 1978, Roma 1982, s. 7-19.

Davies Roy W., The Daily Life of Roman Soldier under the Principate, ANRW 2.1, Berlin-New York 1974, s. 299-338.

Degrassi Attilio, I Fasti Consolari dell'Impero Romano: dal 30 avanti Cristo al 613 dopo Cristo, Roma 1952.

De Pascale Maria R., Sul suicidio del miles, Labeo 31 (1985), s. 57-61.

Der Gnomon de Idios Logos. Bd. 1: der Text (= Ägyptische Urkunden aus den Staatlichen Museen zu Berlin. Griechische Urkunden. Bd. 5) oprac. W. Schubart, Berlin 1919.

Der Gnomon des Idios Logos. Bd. 2: Kommentar (= ̈̈gyptische Urkunden aus den Staatlichen Museen zu Berlin. Griechische Urkunden. Bd. 5), oprac. Woldemar Graf Uxkull-Gyllenband, Berlin 1934.

Fündling Jörg, Kommentar zur Vita Hadriani der Historia Augusta, Bonn 2006.

Gatier Pierre-Louis, La Legio III Cyrenaica et l'Arabie, w: Yann Le Bohec (réd.), Les legions de Rome sous le Haut-Empire. Actes du Congrès de Lyon (17-19 septembre 1998), Lyon 2000, s. 314-349. 
Gilliam Frank J., An Egyptian cohort in A.D.117, Bonner Historia-Augusta-Colloquium 1964/1965, Red. A. Alföldi, Bonn 1966, s. 91-97.

Gilliam Frank J., Some Roman elements in Roman Egypt, w: Frank J. Gilliam, Roman Army Papers, Amsterdam 1986, s. 409-425.

Gilliam Frank J., The veterans and praefectus castrorum of the II Traiana A.D. 157, w: Frank J. Gilliam, Roman Army Papers, Amsterdam 1986, s. 145-161.

Haensch Rudolf, The Roman Army in Egypt, w: Christina Riggs (ed.), The Oxford Handbook of Roman Egypt, Oxford 2012, s. 68-82.

Hübner Heinz, Zur Rechtspolitik Kaiser Hadrians, w: Heinz Hübner, Ernst Klingmüller, Andreas Wacke (red.), Festschrift für Erwin Seidl zum 70. Geburtstag, Köln 1975, s. 61-74.

Keenan James G., Manning Joseph G., Yiftach-Firanko Uri (eds.), Law and legal practice in Egypt from Alexander to the Arab conquest, Cambridge 2014.

Keppie Lawrence J.F., The History and Disappearance of the legion XXII Deiotariana, w: Lawrence Keppie, Legions and veterans. Roman Army papers 1971-2000, Stuttgart 2000, s. $225-232$.

Keppie Lawrence J.F., The Legionary Garrison of Judaea under Hadrian, w: Lawrence Keppie, Legions and veterans. Roman Army papers 1971-2000, Stuttgart 2000, s. 219-224.

Kłodziński Karol, Sekretarze ab epistulis $i$ a libellis $w$ kancelarii cesarzy od Augusta do Hadriana, Torun 2011.

Koeppel Gerhard M., The Column of Trajan: Narrative Technique and the Image of the Emperor, w: Philip A. Stadter, Luc Van der Stockt (eds.), Sage and emperor: Plutarch, Greek intellectuals, and Roman power in the time of Trajan (98-117 A.D.), Leuven 2002, s. 245-258.

Krawczuk Aleksander, Virtutis ergo. Nadania obywatelstwa rzymskiego przez wodzów republiki, Kraków 1963.

Kuryłowicz Marek, Taedium vitae $w$ rzymskim prawie karnym, w: Henryk Kowalski, Marek Kuryłowicz (red.), Contra leges et bonos mores. Przestęstwa obyczajowe w starożytnej Grecji i Rzymie, Lublin 2005, s. 189-199.

Link Stefan, Konzepte der Privilegierung römischer Veteranen, Stuttgart 1999.

Luć Ireneusz, Disciplina militaris - charakter relacji między rzymskim dowódcą a żotnierzami, w: Romanitas \& christianitas : Stanislao Ptodzień (1913-1962) in memoriam, Lublin 2008, s. 83-93.

Luć Ireneusz, Hadrian's Military Coins. The Types COHORTES PRAETORIAE, EXERCITUS and DISCIPLINA AUGUSTI, w: Edward Dąbrowa, Maria Dzielska, Maciej Salomon, Sławomir Sprawski (red.), Hortus Historiae. Księga pamiątkowa ku czci profesora Józefa Wolskiego w setna rocznicę urodzin, Kraków 2010, s. 367-384.

Martin Fernando, La documentacion gregia de la cancilleria del emperador Adriano, Pamplona 1982.

Meyer Paul, Die ägyptischen Urkunden und das Eherecht der römischen Soldaten, ZSS 1898/18, s. 44-74.

Oliver James H., Greek constitutions of Early Roman Emperors from Inscriptions and Papyri, Philadelphia 1989.

Palma Antonio, Benignior interpretatio. Benignitas nella giurisprudenza e nella normazione da Adriano ai Severi, Torino 1997.

Parker Henry M.D., The Roman legions, Chicago 1980.

Phang Sara E., The marriage of Roman soldiers (13 B.C.-A.D, 235): law and family in the imperial army, Leiden-Boston-Köln 2001. 
Phang Sara E., Roman Military Service. Ideologies of Discipline in the Late Republic and Early Principate, Cambridge 2008.

Sander Erich, Das Recht des Römischen Soldaten, Rheinisches Museum für Philologie, Neue Folge, 101. 2. (1958), s. 152-191.

Scarano Ussani Vincenzo, Il „testamentum militis” nell'età di Nerva e Traiano, w: Vincenzo Giuffrè (red.), Sodalitas. Scritti in onore di Antonio Guarino, t. 3, Napoli 1984, s. 1383-1395.

Sitek Bronislaw, Infamia w ustawodawstwie cesarzy rzymskich, Olsztyn 2003.

Smallwood Mary E., Documents Illustrating the Principates of Nerva Trajan and Hadrian, Cambridge 1966.

Sokala Andrzej, The effectiveness of the "ne prostituatur" clauses in Roman law, EOS 1993/81, s. $97-100$.

Speidel Michael P., Emperor Hadrian's speeches to the African army: a new text, Mainz 2006.

Stäcker Jan, Princeps und miles. Studien zum Bindungs- und Nahverhältnis ven Kaiser und Soldat im 1. Und 2. Jahrhundert n. Chr., Zürich-New York 2003.

Świętoń Adam, Tadajczyk Konrad T., 'Edictum Domitiani de privilegiis veteranorum'. Edykt cesarza Domicjana o przywilejach weteranów, Zeszyty Prawnicze 2014/14.4, s. 5-17.

Wacke Andreas, Estudios de derecho Romano y moderno. En cuatro idiomas, Madrid 1996.

Wells Colin, Cesarstwo rzymskie, Warszawa 2005.

Wilcken Urlich, Aegyptische Urkunden aus den Königlichen Museen zu Berlin, Griechische Urkunden I, Berlin 1901.

Wilcken Urlich, Ein Neuer Brief Hadrians, Hermes 1902/37, s. 84-90.

Adam ŚWIĘTOŃ, Konrad TADAJCZYK

\section{EPISTULA HADRIANI DE BONORUM POSSESIONE LIBERIS MILITIUM DANDA THE LETTER OF EMPEROR HADRIAN ON THE INHERITANCE RIGHTS OF SOLDIERS' CHILDERN}

\section{( Sum mary)}

Starting from the 1 st century $\mathrm{AD}$, the marriages of Roman soldiers were banned in order to prevent the military discipline. In consequence the union between the soldiers and women (mostly peregrine but also Roman citizens) were legally ineffective. Effects of the ban were mainly referable to the private law. The most severe was the illegitimacy of the soldiers' offspring. Liberi illegitimi were not in the potestas of their fathers and had no inheritance rights. But in the case of soldiers' children the concession was made: soldier has a possibility to include the Latine or peregrine in his will (testamentum militis), so his child - as a son of peregrine women - could inherit ex testamento. However, it was not possible to inherit when the soldier died intestate. In his epistula issued in 119 AD emperor Hadrian allowed the soldiers's liberi illegitimi to inherit ab intestato. In the case of bonorum possessio they were appointed as a heirs among other cognates (unde cognati). The article presents the circumstances of issuing and legal effects of the epistula.

Keywords: Roman law; inheritance law; Roman army 